\title{
Pengaruh Upstream Supply Chain Management Pada Kinerja Perusahaan (Studi Pt. Zebra Agrindo Utama Di Kabupaten Jember)
}

\section{The Effect Of Upstream Supply Chain Management to Company Performance (Case Study PT. Zebra Agrindo Utama In District Jember)}

\author{
Bayu Tri Nugroho Handriyono \\ Jurusan Manajemen, Fakultas Ekonomi, Universitas Jember \\ Jln. Kalimantan 37, Jember 68121 \\ e-mail: bayutri23@yahoo.com
}

\begin{abstract}
ABSTRAKSI
Penelitian ini bertujuan untuk mengetahui pengaruh Upstrem Supply Chain Management kepada kinerja perusahaan dengan study perusahaan PT. Zebra Agrindo Utama di Kabupaten Jember. Dengan variabel bebas atau independen dalam penelitian ini antara lain information sharing (X1), long-term relationship (X2), cooperation (X3), process integration (X4) dan variabel terikat atau dependent adalah upstream supply chain management (Y). Sedangkan untuk mengetahui pengaruh terhadap kinerja perusahaan maka menggunakan metode balance score card dengan indikator perspektif keuangan, perspektif pelanggan, perpektif proses bisnis internal, perspektif pertumbuhan dan pembelajaran. Lokasi penelitian ini dilakukan di kabupaten Jember. Data yang digunakan yaitu data primer dan data sekunder. Teknik pengambilan sampel menggunakan Sensus. Metode analisis data menggunakan analisis regresi bergandadan balance score card. Hasil penelitian ini bahwa information sharing, long-term relationship, cooperation, dan process integration berpengaruh signifikan terhadap upstream supply chain management. Sedangkan pada penilaian indikator kineja perusahaan dengan metode balance score card juga menunjukkan kinerja perusahaan berjalan dengan baik
\end{abstract}

Kata Kunci: Upstrem Supply Chain Management, information sharing, long-term relationship, cooperation, dan process integration. 


\section{PENDAHULUAN}

Era globalisasi yang terjadi saat ini menuntut setiap perusahaan agar dapat menyesuaikan diri dengan perubahan yang terjadi dalam lingkungan dunia bisnis. Perusahaan yang hanya mampu bersaing secara lokal akan mengalami kesulitan untuk bertahan, oleh karena itu setiap perusahaan perlu memandang pelanggan, pemasok, dan lokasi kompetitor secara global. Komposisi bahan baku maupun jasa perakitan suatu produk dapat berasal dari berbagai negara, sehingga manajemen rantai pasokan merupakan salah satu fokus perhatian bagi peningkatan kinerja setiap perusahaan dalam menghadapi keunggulan bersaing dari perubahan antara perusahaan dan sesama pemasok.

Perusahaan yang memprioritaskan manajemen rantai pasokan akan menawarkan peluang baru, sehingga dapat mengurangi biaya, meningkatkan mutu dan tanggapan mengenai pengurangan waktu pengirimanan. Rantai pasokan dapat memberikan kesempatan bagi peningkatan keseluruhan kinerja secara hati-hati dalam mengatur mata rantai antara organisasi dari pada hanya menfokuskan perhatian terhadap isu operasi di dalam setiap perusahaan (Tracey \& Vonderembse, 2004).

Pengukuran kinerja merupakan kemampuan perusahaan untuk membuat standar yang diinginkan oleh pelanggan dengan mempertimbangkan biaya produksi dan pemeliharaan yang rendah, peningkatan kualitas produk, mengurangi persediaan barang dalam proses, penurunan biaya penanganan material dan batas waktu penyerahan (Tracey \& Vonderembse, 2004). Lebih spesifik, pengukuran kinerja secara absolut adalah kemampuan yang dimiliki dalam perusahaan dengan tidak mempertimbangkan kinerja pesaing, oleh karena itu kinerja absolut dapat diartikan kemampuan perusahaan dalam: Costs, stock-outs and Lead-time reductions.

Penggunaan strategi rantai nilai untuk menyeleksi pemasoknya dan perusahaan ke dalam sejumlah aktivitas yang berbeda, namun saling berhubungan dalam mencapai tujuan yang diinginkan agar menghasilkan kekuatan secara spesifik dari seluruh penciptaan nilai (value creation) dan system penghantar nilai (value delivery system). Tambahan nilai tersebut diperoleh dari supply chain management (Munjiati, dkk., 2004). Supply Chain Managemen (SCM) mempunyai arti penting dalam membangun supplier agar dapat memaksimumkan nilai dari pelanggan. Kunci efektifitas dari SCM adalah membuat supplier sebagai mitra di dalam strategi perusahan. SCM dapat meningkatkan kinerja setiap perusahaan, namun perlu disadari kelemahan-kelemahan dalam praktek SCM dapat pula menurunkan kinerja dan daya saing perusahaan .

Salah satu perusahaan yang menggunakan manejemen rantai pasokan adalah PT. Zebra Agrindo Utama yang bergerak di bidang pengolahan bahan pangan berupa produksi beras. Untuk memproduksi beras tersebut PT. Zebra Agrindo Utama selam tiga tahun terakhir membutuhkan bahan baku berupa gabah dari petani maupun beras dengan kualitas dan kuantitas yang telah ditentukan oleh perusahaan. Dalam produksinya perusahaan membutuhkan jumlah bahan baku yang disesuaikan dengan permintaan sehingga harus ada kerja sama antara perusahaan dengan pemasok. Selain itu menurut data produksi padi di Kabupaten Jember sangat terbatas (tabel 1) sehingga jumlah pemasok juga terbatas. 
Tabel 1. Perkembangan Luas Panen, Produktivitas dan Produksi Padi 2011-2013

\begin{tabular}{|l|l|l|l|}
\hline Tahun & $\begin{array}{l}\text { Luas Panen } \\
\text { (Ha) }\end{array}$ & Produktivitas & $\begin{array}{l}\text { Produksi } \\
\text { (ton) }\end{array}$ \\
\hline 2011 & 13.203 .643 & 49.80 & 65.756 .904 \\
\hline 2012 & 13.471 .653 & 51,19 & 68.956 .292 \\
\hline 2013 & 13.871 .576 & 52 & 67.232 .221 \\
\hline \multicolumn{3}{|c|}{ Sumber: BPS, Jember, 2014. }
\end{tabular}

Dalam keterbatasan pemasok tersebut perusahaan juga mengalami masalah mengenai dalam penentuan harga beli yang cukup tinggi terutama dari tengkulak atau pemasok utama. Sehingga ada kebijakan pemasok utama dengan kriteria tertentu dan telah dipercaya perusahaan sebagai pasok utama. Sehingga kegiatan produksi perusahaan yang membutuhkan bahan baku bermutu dapat tepenuhi dengan harga yang terjangkau oleh perusahaan.

Menurut Pearce dan Robinson (dalam Mayasari, 2008) industri membutuhkan strategi yang sesuai untuk dapat bertahan di pasar, dapat menghadapi persaingan, ancaman, dan peluang pasar. Industri harus dapat merancang dan memiliki strategi supply chain management untuk dapat mengarahkan jalannya tujuan yang ingin dicapai dalam meningkatkan kinerja perusahaan, sehingga perusahaan dapat bertahan dalam persaingan. Information sharing, long term relationship, cooperation, dan process integration merupakan bagian dari faktorfaktor yang mempengaruhi kinerja supply chain management pada perusahaan.

Berdasarkan penelitian yang dilakukan oleh Rahadi, 2012 tentang pngaruh SCM terhadap kinerja operasional perusahaan, secara empirik menganalisis strategi SCM dengan kinerja perusahaan. Unit analisanya adalah variabel independen adalah SCM dan variabel kinerja diukur dengan operasional perusahaan yaitu Information Sharing, Long-term Relationship, Cooperation dan Process Integration. Hasil penelitian menyebutkan bahwa ke empat variabel tersebut berpengaruh positif terhadap kinerja perusahaan.

Penelitian kali ini yang dilakukan oleh peneliti adalah merupakan penelitian replikasi, dengan maksud untuk menguji kembali hasil penelitian yang dilakukan oleh Rahadi (2012) apakah benar penelitian tersebut dilakukan pada objek yang berbeda dengan karakteristik yang berbeda menghasilkan temuan yang konsisten.

Pembagian informasi Information sharing merupakan elemen penting dalam supply chain management, karena dengan adanya information sharing yang transparan dan akurat dapat mempercepat proses rantai pasokan mulai dari supplier sampai ke pasar atau ketangan konsumen. Hubungan jangka panjang (Long term relationship) bisa tercipta dengan adanya hubungan yang berkesinambungan antara semua pihak yang terlibat dalam supply chain management, dan dengan Kerjasama (Cooperation) yang baik dan saling meguntungkan hal tersebut dapat dilakukan. Selanjutnya yang tidak kalah penting adalah proses yang sitematis (Process Integration) dari penggabungan keseluruhan semua kegiatan yang ada di manajemen rantai pasokan agar semua kegiatan berjalan dengan lancar. 
Kegiatan operasi sebuah perusahaan harus dapat diukur, agar pihak-pihak terkait dapat melihat perkembangan sebuah perusahaan pada setiap periode. Saat ini kinerja perusahaan tidak hanya berkaitan dengan aktivitas keuangan perusahaan saja, tetapi telah berkembang demagan melihat kepuasan pelanggan, produktivitas karyawan, dan inovasi bisnis perusahaan (Rahmasari, 2011). Salah satu cara untuk mengukur kinerja suatu perusahaa adalah dengan menggunakan dengan Balance Score Card

Sejalan dengan latar belakang masalah serta perumusan masalah maka tujuan penelitian ini adalah:

- Untuk menganalisis pengaruh information sharing (pembagian informasi) terhadap kinerja supply chain management pada perusahan.

- Untuk menganalisis pengaruh long term relationship (hubungan jangka panjang) terhadap kinerja supply chain management pada perusahan.

- Untuk menganalisis pengaruh cooperation (kerjasama) terhadap kinerja supply chain management pada perusahan.

- Untuk menganalisis pengaruh process integration (integrasi proses) terhadap kinerja supply chain management pada perusahan.

- Untuk menganalisis perspektif keuangan dan perspektif internal bisnis perusahaan berdasarkan analisis Balance Score Card.

\section{METODE PENELITIAN}

\section{Rancangan Penelitian}

Penelitian yang dilakukan ini adalah penelitian kuantitatif dengan metode explanatory research. Dalam mendeskripsikan penelitian tersebut dan melakukan penilaian kinerja perusahaan dengan menggunakan pendekatan Balance Scorecard yang ditinjau dari empat perspektif yaitu perspektif keuangan, perspektif pelanggan, perspektif proses bisnis internal, dan perspektif pembelajaran dan pertumbuhan

\section{Jenis dan Sumber Data}

Sumber data yang digunakan dalam penelitian ini adalah Data primer yaitu data yang bersumber dari hasil pengamatan (observasi) dan wawancara (interview) dengan pimpinan dan sejumlah pemasok dan karyawan perusahaan. Data sekunder yaitu data yang diperoleh berupa laporan-laporan dan informasi lain yang bersumber dari literature dan informasi lain yang berhubungan dengan penulisan ini

\section{Populasi dan Sampel}

Populasi dalam penelitian ini adalah para pemasok pada Perusahaan PT. Zebra Agrindo Utama di Kabupaten Jember. Metode pengumpulan sampel dalam penelitian ini menggunakan sampling jenuh atau sensus. Dalam penelitian ini karena jumlah populasinya sedikit (terbatas) sehingga tidak memungkinkan untuk menggunakan sampel, sehingga 
penulis mengambil jumlah sampel sama dengan jumlah populasi yaitu 34 pemasok yang terdiri 24 pemasok dengan bentuk bahan baku berupa gabah dan 10 pemasok dengan bahan baku beras. Adapun kriteria yang ditetapkan untuk menentukan sampel atau populasi dalam penelitian ini adalah pemasok pada Perusahaan PT. Zebra Agrindo Utama di Kabupaten Jember baik secara langsung ke gudang ataupun secara tidak langsung pada periode tahun 2013.

\section{Metode Analisis Data}

Metode analisis yang digunakan adalah analisis regresi linier berganda, dimana secara umum formulasi yang digunakan adalah sebagai berikut :

$Y=a+b_{1} X_{1}+b_{2} X_{2}+b_{3} X_{3}+b_{4} X_{4}$

\section{HASIL DAN PEMBAHASAN}

\section{Hasil Penelitian}

\section{Hasil Analisis Regresi Linier Berganda}

Analisi regresi linier berganda dilakukan untuk mengetahui besarnya pengaruh variabel Information sharing, Long term relationship, Cooperation, dan Process integration terhadap Kinerja Upstream Supply Chain Management pada Perusahaan PT. Zebra Agrindo Utama di Kabupaten Jember.

\section{Tabel 1. Hasil Analisis Regresi Linier Berganda}

\begin{tabular}{|l|l|l|l|}
\hline Variabel & B & T & Sig. \\
\hline Constant & $-2,004$ & & \\
\hline $\begin{array}{l}\text { Information } \\
\text { sharing }\end{array}$ & 0,347 & 3,210 & 0,003 \\
\hline $\begin{array}{l}\text { Long term } \\
\text { relationship }\end{array}$ & 0,746 & 5,872 & 0,000 \\
\hline Cooperation & 0,191 & 2,345 & 0,026 \\
\hline $\begin{array}{l}\text { Process } \\
\text { integration }\end{array}$ & 1,051 & 11,13 & 0,000 \\
\hline
\end{tabular}

Sumber: data diolah, 2014.

Model regresi yang dihasilkan adalah sebagai berikut:

Kinerja Upstream Supply Chain Management $=-2,004+0,347$ IS + 0,746 LTR + 0,191 C + $1,051 \mathrm{PI}+\mathrm{e}_{\mathrm{it}}$ 


\section{Uji t}

Dari pengujian regresi parsial maka diperoleh hasil sebagai berikut:

- Nilai signifikansi Information sharing adalah sebesar 0,003 lebih kecil dari nilai signifikansi yang ditetapkan, yaitu a $=0,01$. Nilai ini mengindikasikan bahwa hipotesis pertama yang menyatakan bahwa Information sharing berpengaruh positif signifikan terhadap Kinerja Upstream Supply Chain Management, diterima.

- Nilai signifikansi Long term relationship adalah sebesar 0,000 lebih kecil dari nilai signifikansi yang ditetapkan, yaitu a $=0,01$. Nilai ini mengindikasikan bahwa hipotesis kedua yang menyatakan bahwa Long term relationship berpengaruh positif signifikan terhadap Kinerja Upstream Supply Chain Management.

- Nilai signifikansi Cooperation adalah sebesar 0,026 lebih kecil dari nilai signifikansi yang ditetapkan, yaitu a $=0,05$. Nilai ini mengindikasikan bahwa hipotesis ketiga yang menyatakan bahwa Cooperation berpengaruh negatif signifikan terhadap Kinerja Upstream Supply Chain Management, diterima.

- Nilai signifikansi Process integration adalah sebesar 0,000 lebih kecil dari nilai signifikansi yang ditetapkan, yaitu a $=0,01$. Nilai ini mengindikasikan bahwa hipotesis keempat yang menyatakan Process integration berpengaruh positif signifikan terhadap Kinerja Upstream Supply Chain Management, diterima.

\section{Uji F}

Hasil uji simultan menunjukkan bahwa hasil $\mathrm{F}$ hitung adalah 35,936 (dimana $\mathrm{F}$ hitung $>\mathrm{F}$ tabel : 35,936 > 5,75) dan nilai signifikansi 0,000 lebih kecil dari 5\%. Hal ini berarti bahwa Information sharing, Long term relationship, Cooperation dan Process integration berpengaruh serentak terhadap Kinerja Upstream Supply Chain Management pada Perusahaan PT. Zebra Agrindo Utama di Kabupaten Jember

\section{Hasil Analisis Kinerja Pemasok dengan Balance Score Card}

\section{Perspektif Keuangan}

Dalam pengukuran kinerja pemasok yang dipandang dari perspektif keuangan, digunakan data pada Neraca dan Laporan Laba Rugi pemasok pada tahun 2013. Data yang telah ada tersebut digunakan untuk menghitung rasio keuangan yang meliputi rasio likuiditas, rasio leverage, rasio aktivitas dan rasio profitabilitas. 
Tabel 2. Perspektif Keuangan Pemasok

\begin{tabular}{|c|c|c|c|c|c|}
\hline Nama Pemasok & CR & Leverage & TATO & ROA & ROE \\
\hline Pemasok 1 & $189 \%$ & $36 \%$ & 5,22 & $12 \%$ & $18 \%$ \\
\hline Pemasok 2 & $147 \%$ & $42 \%$ & 6,01 & $24 \%$ & $41 \%$ \\
\hline Pemasok 3 & $172 \%$ & $39 \%$ & 5,21 & $17 \%$ & $29 \%$ \\
\hline Pemasok 4 & $203 \%$ & $32 \%$ & 5,65 & $19 \%$ & $28 \%$ \\
\hline Pemasok 5 & $237 \%$ & $25 \%$ & 6,52 & $20 \%$ & $26 \%$ \\
\hline Pemasok 6 & $159 \%$ & $39 \%$ & 5,99 & $18 \%$ & $30 \%$ \\
\hline Pemasok 7 & $229 \%$ & $29 \%$ & 5,60 & $24 \%$ & $34 \%$ \\
\hline Pemasok 8 & $202 \%$ & $31 \%$ & 6,07 & $18 \%$ & $26 \%$ \\
\hline Pemasok 9 & $204 \%$ & $31 \%$ & 5,79 & $13 \%$ & $19 \%$ \\
\hline Pemasok 10 & $216 \%$ & $29 \%$ & 6,08 & $14 \%$ & $20 \%$ \\
\hline Pemasok 11 & $193 \%$ & $33 \%$ & 5,89 & $25 \%$ & $37 \%$ \\
\hline Pemasok 12 & $171 \%$ & $39 \%$ & 5,43 & $17 \%$ & $28 \%$ \\
\hline Pemasok 13 & $195 \%$ & $31 \%$ & 6,30 & $27 \%$ & $39 \%$ \\
\hline Pemasok 14 & $202 \%$ & $30 \%$ & 6,15 & $21 \%$ & $31 \%$ \\
\hline Pemasok 15 & $193 \%$ & $36 \%$ & 4,96 & $10 \%$ & $16 \%$ \\
\hline Pemasok 16 & $214 \%$ & $30 \%$ & 5,91 & $13 \%$ & $19 \%$ \\
\hline Pemasok 17 & $239 \%$ & $31 \%$ & 4,68 & $17 \%$ & $25 \%$ \\
\hline Pemasok 18 & $180 \%$ & $34 \%$ & 6,08 & $13 \%$ & $19 \%$ \\
\hline Pemasok 19 & $263 \%$ & $29 \%$ & 4,07 & $10 \%$ & $14 \%$ \\
\hline Pemasok 20 & $183 \%$ & $35 \%$ & 5,72 & $18 \%$ & $28 \%$ \\
\hline Pemasok 21 & $193 \%$ & $32 \%$ & 6,11 & $15 \%$ & $22 \%$ \\
\hline Pemasok 22 & $163 \%$ & $36 \%$ & 6,47 & $15 \%$ & $24 \%$ \\
\hline Pemasok 23 & $158 \%$ & $37 \%$ & 7,20 & $21 \%$ & $34 \%$ \\
\hline Pemasok 24 & $168 \%$ & $41 \%$ & 7,08 & $12 \%$ & $21 \%$ \\
\hline
\end{tabular}




\begin{tabular}{|l|l|l|l|l|l|}
\hline Pemasok 25 & $106 \%$ & $61 \%$ & 8,00 & $21 \%$ & $55 \%$ \\
\hline Pemasok 26 & $113 \%$ & $40 \%$ & 7,84 & $17 \%$ & $28 \%$ \\
\hline Pemasok 27 & $195 \%$ & $43 \%$ & 8,26 & $19 \%$ & $34 \%$ \\
\hline Pemasok 28 & $164 \%$ & $56 \%$ & 7,08 & $28 \%$ & $39 \%$ \\
\hline Pemasok 29 & $172 \%$ & $42 \%$ & 8,00 & $18 \%$ & $31 \%$ \\
\hline Pemasok 30 & $186 \%$ & $67 \%$ & 9,06 & $26 \%$ & $25 \%$ \\
\hline Pemasok 31 & $186 \%$ & $63 \%$ & 10,44 & $26 \%$ & $24 \%$ \\
\hline Pemasok 32 & $190 \%$ & $69 \%$ & 8,19 & $21 \%$ & $34 \%$ \\
\hline Pemasok 33 & $157 \%$ & $53 \%$ & 8,16 & $20 \%$ & $26 \%$ \\
\hline Pemasok 34 & $163 \%$ & $44 \%$ & 8,02 & $16 \%$ & $29 \%$ \\
\hline
\end{tabular}

Sumber: data diolah, 2014.

\section{Rasio Likuiditas.}

Rasio likuiditas digunakan untuk mengukur kemampuan dalam memenuhi kewajiban jangka pendeknya. Berdasarkan hasil perhitungan, Current ratio para pemasok beras ke PT. Zebra Agrindo Utama di Kabupaten Jember pada tahun 2013 adalah tinggi. Current ratio yang terlalu tinggi menunjukkan bahwa perusahaan melakukan investasi yang melampaui batas/ berlebih pada aset lancar.

\section{Rasio Laverage}

Rasio leverage (hutang) adalah rasio yang menunjukkan sejauh mana perusahaan dibiayai oleh hutang (Tatang, 2011). Rasio total debt to total assets pemasok pada tahun 2013 adalah lebih kecil dari 45\%, dan termasuk kategori bagus, karena berdasarkan kriteria rasio keuangan, nilai leverage yang $<45 \%$ masuk dalam kategori bagus (Tatang, 2011). Rasio total debt to total assets menekankan pada peran penting pendanaan utang bagi perusahaan denagn menunjukkan persentase aktiva perusahaan yang didukung oleh pendanaan hutang. Total debt to total assets Sujak adalah $42 \%$ dapat diartikan bahwa $42 \%$ dari aktiva perusahaan didanai oleh hutang, sementara sisanya 58\% pendanaan berasal dari modal sendiri. Semakin besar persentase pendanaan yang disediakan oleh modal sendiri maka semakin besar jaminan perlindungan yang didapat oleh kreditur perusahaan atau dengan kata lain, semakin tinggi rasio total debt to total assets maka semakin besar resiko keuangannya, sebaliknya semakin rendah rasio total debt to total assets maka akan semakin rendah resiko keuangannya. 


\section{Rasio Aktivitas}

Rasio aktivitas disebut juga rasio efisiensi yaitu rasio yang menunjukkan seberapa efektif perusahaan dalam menggunakan berbagai aktivanya (Tatang, 2011). Total Assets Turnover pada semua pemasok pada tahun 2013 adalah lebih dari 5 kali, dan hanya TATO Ripin, Muhyit dan P.Diana dibawah 5 kali. Ini berarti Total Assets Turnover para pemasok pada tahun 2013 termasuk kategori bagus, karena berdasarkan rasio keuangan, TATO dikatakan bagus jika memiliki perputaran lebih dari 5 kali (Tatang, 2011). Total Assets Turnover 6,633 kali dapat diartikan bahwa dana yang tertanam dalam keseluruhan aktiva rata-rata dalam satu tahun berputar lebih darin 5 kali atau setiap rupiah dalam satu tahun menghasilkan revenue lebih dari Rp 5. Ini mengindikasikan bahwa PT. Zebra Agrindo Utama di Kabupaten Jember sudah efisien dalam menggunakan sumber dayanya dalam hal ini investasi dalam piutang dan persediaan terlalu besar.

\section{Rasio Profitabilitas}

Rasio profitabilitas adalah rasio yang menghubungkan laba dari penjualan dan investasi. ROA para pemasok pada tahun 2013 secara keseluruhan adalah lebih besar dari 8\%, sehingga termasuk kategori bagus, karena berdasarkan ketentuan rasio keuangan nilai ROA dikatakan bagus jika nilainya $>8 \%$ (Tatang, 2011).

Return On Equity pada pemasok tahun 2013 adalah lebih besar dari 8\%, sehingga termasuk kategori bagus, karena berdasarkan ketentuan rasio keuangan ROE dikatakan bagus jika memiliki nilai $>8 \%$ (Tatang, 2011).

\section{Perspektif Internal Bisnis}

Pengukuran perspektif internal bisnis para pemasok dilaksanakan terhadap semua aktivitas yang dilakukan oleh perusahaan dalam menciptakan suatu produk. Penilaian kinerja dari perspektif ini menggunakan tolok ukur inovasi produk dan proses operasi. Proses operasi para pemasok rata-rata sama semua karena mereka sama-sama memasok gabah. Penilaian kriteria dapat dilihat pada tabel di bawah ini berdasarkan lampiran 8 :

Tabel 3. Analisis Prespektif Internal Bisnis

\begin{tabular}{|c|c|c|c|c|}
\hline No & Indikator & $\%$ & Kategori & Skor \\
\hline 3 & $\begin{array}{l}\begin{array}{lr}\text { Kesesuaian } & \text { kualitas } \\
\text { produk } & \text { antara } \\
\text { konsumen } & \text { dengan } \\
\text { pemasok. }\end{array} \\
\begin{array}{l}\text { Kepuasan } \\
\text { akan ketepatan waktu } \\
\text { pengiriman }\end{array} \\
\begin{array}{l}\text { Fleksibilitas } \\
\text { dalam pemasok } \\
\text { perubahan }\end{array}\end{array}$ & $\begin{array}{l}92,9 \\
88,8 \\
2 \\
\\
55,3 \\
\end{array}$ & $\begin{array}{l}\text { Sangat } \\
\text { Puas }\end{array}$ & 5 \\
\hline
\end{tabular}




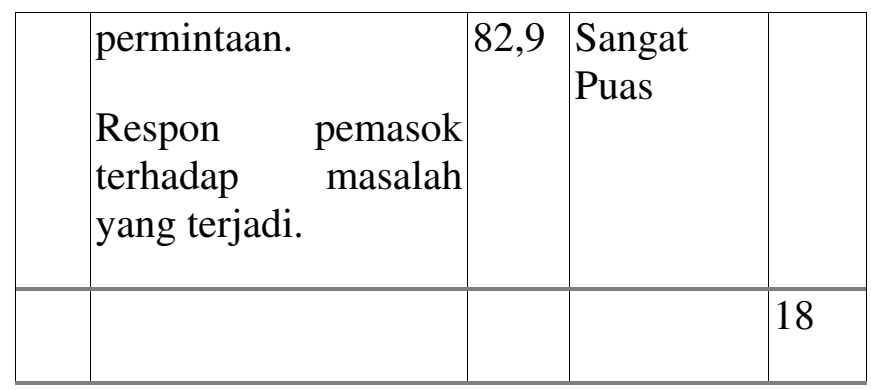

Sumber: data diolah, 2014.

Berdasarkan hasil tabel tersebut maka pemenuhan produk dengan kualitas produk yang telah ditentukan dapat dipenuhi oleh pemasok sebesar 92,9\%. Pada kriteria ketepatan waktu pengiriman produk (gabah) yang telah dipesan pemasok menilai tenggat waktu pengiriman yang ditentukan konsumen dinilai sangat memuaskan dengan nilai $88,82 \%$. Karena akan memberikan waktu bagi pemasok untuk mencari bahan baku yang sesuai kualitas yang telah ditentukan. Sedangkan pada kriteria fleksibilitas pemasok dalam menanggapi perubahan permintaan konsumen hanya memiliki nilai 55,3\% atau cukup. Karena perubahan permintaan yang terjadi baik dalam bentuk kualitas dan kuantitas dapat mengubah proses yang telah ada, karena pemasok di pengaruhi oleh persediaan yang tersedia. Tetapi pemasok memiliki respon baik terhadap masalah-masalah yang terjadi baik masalah pengiriman, kualitas, dan kuantitas produk dengan nilai $82,9 \%$. Sehingga kesimpulan keseluruhan perspektif internal bisnis pemasok terhadap konsumen PT. Zebra Agrindo Utama sangat baik dengan presentase 92,9\%. Sehingga secara keseluruhan prespektif internal bisnis masuk dalam kategori sangat bagus karena memiliki nilai $90 \%$ yang masuk dalam kategori sangat puas.

\section{Pembahasan}

\section{a. Pengaruh Information sharing terhadap Kinerja Supply Chain Management pada Perusahaan PT. Zebra Agrindo Utama di Kabupaten Jember}

Berdasarkan hasil analisis regresi linier berganda, nilai signifikansi Information sharing adalah sebesar 0,003 lebih kecil dari 0,01 , sehingga hipotesis pertama yang menyatakan bahwa information sharing berpengaruh terhadap supply chain management pada Perusahaan PT. Zebra Agrindo Utama di Kabupaten Jember, diterima.

Hasil analisis menunjukkan bahwa PT. Zebra Agrindo Utama di Kabupaten Jember telah memberikan informasi kepada pemasok (terutama petani beras) berupa harga, sistem pertanian, dan produk olahan yang dapat masuk di gudang, production, dan design, selalu bertukar informassi dengan pemasok (petani beras) di Kabupaten Jember, selalu memberikan informasi mengenai harga, pelatihan, dan lain-lain utamanya terkait dengan bahan baku beras, dan memberikan informasi yang berguna bagi setiap pihak yang menjadi pemasok dari perusahaan, sehingga dapat meningkatkan mutu aktivitas aliran dan perpindahan barang dari petani beras sebagai pemasok ke perusahaan PT. Zebra Agrindo Utama di Kabupaten Jember atau sebaliknya. 


\section{b. Pengaruh Long Term Relationship terhadap Kinerja Supply Chain Management pada Perusahaan PT. Zebra Agrindo Utama di Kabupaten Jember}

Berdasarkan hasil analisis regresi linier berganda, nilai signifikansi Long term relationship adalah sebesar 0,000 lebih kecil dari 0,01, sehingga hipotesis kedua yang menyatakan bahwa long term relationship berpengaruh terhadap supply chain management pada Perusahaan PT. Zebra Agrindo Utama di Kabupaten Jember, diterima.

Hasil analisis menunjukkan bahwa PT. Zebra Agrindo Utama di Kabupaten Jember telah melakukan kerja sama dengan pemasok dengan jangka waktu sekali panen atau lebih, PT. Zebra Agrindo Utama di Kabupaten Jember telah melakukan hubungan jangka panjang atas kerja sama yang saling menguntungkan antar pihak terkait dan PT. Zebra Agrindo Utama di Kabupaten Jember telah melakukan hubungan dalam jangka waktu sekali panen atau lebih sehingga dapat meningkatkan mutu aktivitas aliran dan perpindahan barang dari petani beras sebagai pemasok ke perusahaan PT. Zebra Agrindo Utama di Kabupaten Jember

\section{c. Pengaruh Cooperation terhadap Kinerja Supply Chain Management pada Perusahaan PT. Zebra Agrindo Utama di Kabupaten Jember}

Berdasarkan hasil analisis regresi linier berganda, nilai signifikansi Cooperation adalah sebesar 0,026 lebih kecil dari 0,05, sehingga hipotesis ketiga yang menyatakan bahwa cooperation berpengaruh terhadap supply chain management pada Perusahaan PT. Zebra Agrindo Utama di Kabupaten Jember, diterima.

Hasil analisis menunjukkan bahwa PT. Zebra Agrindo Utama di Kabupaten Jember melakukan Diskusi dengan pemasok dalam perencanaan dan penjualan bahan baku, melakukan kerja sama yang obyektif sehingga saling menguntungkan antar pihak terkait dan secara terus-menerus melakukan peningkatan kualitas hubungan dengan pemasok, sehingga dapat meningkatkan mutu aktivitas aliran dan perpindahan barang dari petani beras sebagai pemasok ke perusahaan PT. Zebra Agrindo Utama di Kabupaten Jember atau sebaliknya seperti adanya kesepakatan dan tujuan bersama, kepercayaan yang baik dan budaya organisasi yang sesuai.

\section{d. Pengaruh Process integration terhadap Kinerja Supply Chain Management pada Perusahaan PT. Zebra Agrindo Utama di Kabupaten Jember}

Berdasarkan hasil analisis regresi linier berganda, nilai signifikansi Process integration adalah sebesar 0,000 lebih kecil dari 0,05, sehingga hipotesis keempat yang menyatakan bahwa process integration berpengaruh terhadap supply chain management pada Perusahaan PT. Zebra Agrindo Utama di Kabupaten Jember, diterima.

Hasil analisis menunjukkan bahwa PT. Zebra Agrindo Utama di Kabupaten Jember telah melakukan melakukan peningkatan aktivitas logistik baik dari perusahaan ke pemasok atau sebaliknya, memiliki integritas dalam aktivitas logistik dengan pemasok dan memiliki efektifitas dalam penyaluran arus material dari perusahaan ke petani atau sebaliknya, sehingga dapat meningkatkan mutu aktivitas aliran dan perpindahan barang dari petani beras sebagai pemasok ke perusahaan PT. Zebra Agrindo Utama di Kabupaten Jember. 


\section{Kinerja Pemasok dengan Konsep Balance Score Card}

\section{a. Perspektif Keuangan}

Perspektif keuangan menggunakan tolok ukur rasio likuiditas, leverage, aktivitas dan profitabilitas. Berdasarkan hasil penelitian, untuk rasio likuiditas, diketahui current ratio adalah tinggi. Hal ini mengindikasikan ada investasi yang melampaui batas/ berlebih pada aset lancar. Dalam rasio leverage ini digunakan indikator total debt to total asset. Total debt to total assets yang dicapai Pemasok pada tahun 2013 adalah sebesar lebih kecil dari $45 \%$ dan termasuk kategori bagus (Tatang, 2011). Total assets turnover Pemasok pada tahun 2013 adalah lebih besar dari 5 kali, termasuk kategori bagus (Tatang, 2011). Hal ini menunjukkan bahwa pemasok sudah efisien dalam menggunakan sumber dayanya. ROA Pemasok pada tahun 2013 adalah lebih besar dari 8\%, termasuk kategori bagus. Hal ini dikarenakan keuntungan yang diperoleh pemasok sudah tinggi. Return On Equity pada Pemasok pada tahun 2013 adalah lebih besar dari 8\%, termasuk kategori bagus (Tatang, 2011).

\section{b. Perspektif Proses Bisnis Internal}

Pemasok dinilai sangat baik Karena dapat menyesuaikan kualitas produk yang diminta oleh perusahaan dan mampu memenuhi permintaan pengiriman bahan baku sesuai dengan keinginan konsumen. Tetapi pemasok mengalami kesulitan dalam fleksibilitas permintaan konsumen karena pemasok mengalami keterbatasan persediaan produk dan keterbatasan waktu pengiriman.

\section{SIMPULAN}

Berdasarkan hasil penelitian dapat diambil beberapa kesimpulan, yaitu:

- Hasil penelitian menunjukkan bahwa information sharing berpengaruh terhadap supply chain management pada Perusahaan PT. Zebra Agrindo Utama di Kabupaten Jember.

- Hasil penelitian menunjukkan bahwa long term relationship berpengaruh terhadap supply chain management pada Perusahaan PT. Zebra Agrindo Utama di Kabupaten Jember.

- Hasil penelitian menunjukkan bahwa cooperation berpengaruh terhadap supply chain management pada Perusahaan PT. Zebra Agrindo Utama di Kabupaten Jember. .

- Hasil penelitian menunjukkan bahwa process integration berpengaruh terhadap supply chain management pada Perusahaan PT. Zebra Agrindo Utama di Kabupaten Jember.

- Analisis hasil penelitian berdasar Balanced Score Card dilihat dari perspektif keuangan termasuk kategori bagus. Perusahaan sudah efisien dalam mengggunakan modalnya dan keuntungan yang diperoleh perusahaan juga sangat tinggi. Kepuasan pelanggan dari hasil analisis statistik deskriptif persentase diperoleh hasil 90\%, yang berarti pelanggan merasa puas dengan pelayanan yang ditawarkan perusahaan, baik itu meliputi harga produk, kualitas maupun pelayanan perusahaan. Inovasi produk yang dihasilkan terserap $75 \%$ dari keseluruhan produk baru dan proses operasi dilakukan dalam hari. Sehingga dapat disimpulkan bahwa proses bisnis internal yang dicapai sudah bagus. 


\section{KETERBATASAN PENELITIAN}

Penelitian ini dalam pelaksanaannya juga memiliki keterbatasan, yaitu keterbatasan dalam mencari referensi dan literatur sehingga wawasan tehadap konsep upstream supply chain management kurang maksimal. Selain hal tersebut, keterbatasan dalam mengumpulkan informasi dari pelanggan dan pemasok karena peneliti mencari informasi pada masingmasing pelanggan dan pemasok dimana ada beberapa dari mereka yang tidak memberikan informasi secara keseluruhan dengan alasan rahasia perusahaan, sehingga peneliti hanya bisa menyimpulkan sedikit informasi dari yang didapat.

\section{UCAPAN TERIMA KASIH}

Penulis mengucapkan terima kasih kepada responden yaitu pemasok tetap PT. Zebra Agrindo Utama di Kabupaten Jember yang telah meluangkan waktu untuk mengisi kuesioner dan memberikan informasi berkaitan dengan data yang penulis teliti.

\section{DAFTAR REFERENSI}

Tracey and Vonderembse. 2004. Building Supply Chain : A Key To Enhancing Manufacturing Performance”. Journal of Business Mid-American.

Munjiati Munawaraoh, dkk,. 2004.Manajemen Operasi. Unit Penerbiatan Fakultas Ekonomi. (UPFE-UMY) Yogyakarta.

Viona Mayasari.2008.“Analisis Strategi Bersaing Industri Kecil Makanan Tradisional Khas Kota Payakumbuh”. Skripsi. Bogor:IPB.

Dedi Rianto Rahadi.2012.“Pengaruh Supply Chain Management Terhadap Kinerja Operasional Perusahaan”.Proceeding Seminar Sistem Produksi X.

Lisda Rahmasari. (2011). Pengaruh Supply Chain Management Terhadap Kinerja Perusahaan dan Keunggulan Bersaing. Majalah Ilmiah Informatika Vol. 2 No. 3. Fakultas Ekonomi Universitas AKI

Tatang Ary Gumanti. 2011. Manajemen Investasi. Bogor: Mitra Wacana Media Yogyakarta. 